\title{
EMPIRICAL RESEARCH RESULTS REGARDING THE INFLUENCE OF CONTROLLING ON ORGANISATIONAL PERFORMANCE
}

\author{
AGNIESZKA BIEŃKOWSKA
}

\begin{abstract}
A B S T R A C T
The article aims to explain how controlling influences an organisation as a whole, considering the job performance of employees and managers. It describes the development and verification of the Controlling Effectiveness Model, which characterises the impact, the place of each variable and the direction of each relationship in the effort to shape organisational performance. The hypothesis was verified with the help of empirical research, which was conducted with 264 organisations operating in Poland. The survey took place in October 2019. The authors of the article used the CAWI method. Efforts had been made to ensure a diversified research sample encompassing various organisational characteristics. The exploratory and confirmatory factor analysis and the sequentially mediated regression model were used to verify the hypothesis. The empirical research allowed confirming a statistically significant indirect impact of the quality of controlling on organisational performance. This relationship depends on the job performance of managers and employees. The analysis of the impact made by controlling on the job performance of employees and managers as we as the organisational performance resulted in a mediation model (the Controlling Effectiveness Model) and confirmed the effect of controlling on organisational performance through the impact on job performance of managers and employees. The article has practical implications. The organisations that decide to implement controlling should focus on the quality of this management support method. It is not enough to simply implement controlling as organisations need to ensure the correct implementation. In this context, it is also relevant to properly shape functional, organisational and instrumental controlling solutions (tailored to the characteristics of the organisation as a whole, as well as to the environmental conditions, under which the organisation operates), which determine the quality of controlling.
\end{abstract}

KEY WORDS

management, controlling, organisational performance, Controlling Effectiveness Model, empirical research

10.2478/emj-2020-0017
Corresponding author:

Agnieszka Bieńkowska

Wroclaw University of Science and Technology, Poland ORCID 0000-0002-7498-6322 e-mail: agnieszka.bienkowska@pwr.edu.pl

\section{INTRODUCTION}

Even though the notion of the effectiveness of management methods is not new, it is still important from a practical and theoretical point of view. Although according to Zimniewicz (2013, p. 167), "management concepts are full of promises", the management of an organisation expects a real positive impact on the organisation as a whole when deciding to implement solutions for a specific management method. The literature discusses the goals for

Bieńkowska, A. (2020). Controlling Effectiveness Model - empirical research results regarding the influence of controlling on organisational performance. Engineering Management in Production and Services, 12(3), 28-42. doi: 10.2478/emj-20200017 
implementing individual management methods and the results of their implementation (Bieńkowska \& Zgrzywa-Ziemak, 2011). The goals of the management methods are considered in the intentional approach, and the results inform about the specific effect achieved in an organisation. However, both goals and results essentially relate to the benefits associated with the implementation of a specific method. Benefits are diverse in terms of goals or results and may concern the reference areas, e.g. strategic, managerial, social, economic and technological (Bieńkowska \& Zgrzywa, 2011).

Organisational performance is one of the most important performance parameters of organisational functioning, next to its productivity, efficiency or effectiveness. It is understood as a multidimensional construct (Richard et al., 2009; Tworek \& Sałamacha, 2019; Maletic, 2015; Sujová et al., 2019; Bieńkowska et al., 2020), related to the results of organisational functioning. The improvement of organisational performance is among discussed benefits of management methods planned for implementation; however, it is practically never defined as a direct goal of such methods. It is a synthetic construct, which can be influenced indirectly and financially by exerting influence on different areas (depending on a method) of the organisational functioning (Richard et al., 2009; Benčová \& Kalavská, 2009; Rylková, 2015). However, insufficient specific empirically verified models are available in the literature that would explain the impact of current management methods on organisational performance.

The above remark also applies to controlling, which is among the most frequently implemented management methods in Poland (Bieńkowska \& Zgrzywa-Ziemak, 2011; Lisiński et al., 2012; Tworek, 2019) and the world (Tworek, 2019). According to Weber $(2019$, p. 125), "In the past two decades, controlling has experienced quite a victory march. This is true for both business practice and academia". In a way, the popularity of controlling proves that it is possible to achieve measurable benefits appreciated by entrepreneurs in an organisation. The main benefits of implemented controlling are:

- ensured continuity of functioning and stimulated development of the organisation (Bea, Friedl \& Schweitzer, 2005; Chachuła, 2009; Kuc, 2002);

- improved efficiency and competitiveness of the organisation as a whole (Nowosielski, 2001; Marciniak, 2008; Kuc, 2002);

- optimised (maximised) financial results (Brzezin, 2001);
- ensured economic efficiency (profitability) and financial liquidity (Hahn \& Hungenberg, 2001);

- ensured sustained and systematic improvement in economic performance (Kuc, 2002).

Organisational performance is obviously named as one of the most important benefits of implemented controlling (Bieńkowska et al., 2019a; Bieńkowska et al., 2019b; Tworek, 2019), and it is treated as a general result parameter referring to the organisation as a whole. Unfortunately, so far, the literature has not explained the mechanism of the influence made by controlling on this parameter of the organisational functioning, and this issue still constitutes a research gap in management sciences. Therefore, this article aims to explain the mechanism behind the influence made by controlling on the organisational performance. The conducted research assumed that the influence of controlling on organisational performance is indirect. For example, the results obtained by Bieńkowska et al. (2019c) confirmed that job performance acts as a mediator in the relationship between the use of controlling measures and organisational performance. However, it should be noted that controlling - as a method for the support of the management - primarily affects the performance of managers, who in turn influence employees by building their job performance. However, it is not enough to consider the implementation of controlling alone (i.e., whether to implement and for what period, cf. Bieńkowska et al., 2019a, 2019b) as it is necessary to also reflect on their quality, which translates into the influence of controlling on the functioning of the organisation as a whole. Weber and Nevries (2012) emphasised the need to focus controlling on an internal customer. Therefore, the correct functioning of controlling in an organisation, which is tailored to the needs of managers and employees, determines its effectiveness (Bieńkowska, 2015).

The identified mechanism of the influence made by controlling on organisational performance constitutes the basis for the development of the Controlling Effectiveness Model, assuming that the effectiveness of controlling is understood in this article as the strength of the influence made by controlling on organisational performance. Therefore, the obtained results not only allow explaining how controlling affects the results of organisational functioning, but they also help to develop the Controlling Effectiveness Model, which allows filling the previously identified research gap. 
The theoretical part of the article presents the essence of controlling as a management-support method and refers to the quality of its products and services. It demonstrates the impact of controlling on organisational performance, considering the influence of the discussed method on organisational performance through the job performance of managers and employees. In terms of the Controlling Effectiveness Model, the empirical part examines the mechanism of the impact made by controlling on organisational performance. The Controlling Effectiveness Model is verified using the path analysis executed with the help of SPSS AMOS. The obtained research are discussed and summarised.

\section{NOTION AND QUALITY OF CON- TROLLING}

Controlling is a management-support method, which on the one hand is one of the most frequently implemented methods in modern organisations (Bieńkowska \& Zgrzywa-Ziemak, 2011; Tworek, 2019), and on the other hand, it still raises a number of controversies related to its different perception in and within different countries (Mocanu, 2014; Guenter, 2013; Schäffer \& Binder, 2008; Chenhall, 2003; Wagenhofer, 2006; Schäffer et al., 2001). These controversies primarily result from the multithreaded history of controlling, which promotes differences in the perception around the world.

The modern understanding of controlling was created in the USA, in close relation to management accounting from the very beginning. In this country, both the profession of "controller" and the term "controllership" have been established to describe all activities carried out by controllers (Jackson, 1949; Goto et al., 2014). The American perception of controlling was adopted after World War II by some European countries (especially English-speaking). So today, controlling in the US and some European countries is combined with management and is referred to as "managerial/management control" (Otley, 1994; Otley, 1999; Granlund \& Taipaleenmäki, 2005; Anthony \& Govindarajan, 2007; Malmi \& Brown, 2008; Strauß \& Zecher, 2013) or "managerial/management control and accounting" (Otley \& Emmanuel, 2013). However, "management control systems provide information that is intended to be useful to managers in performing their jobs and to assist organisations in developing and maintaining viable patterns of behaviour" (Otley, 1999, p. 364). In these countries, the term "controlling" is relatively rarely used and usually replaced with the term "managerial accounting" (Luther, Joes \& Saxl, 2010, pp. 1-2). A different situation is in Germany, where a different view has emerged on this management support method. First of all, the term "controlling" in its modern understanding was created in Germany (Deyhle, 1976), and understood as a subsystem of organisational management support (Horvath, 2006), support for planning and coordinating subsystems (Reichmann, 2011; Horvath, 2002; Janka \& Günther, 2020), coordination of the management system (Küpper, 2008), or the way to ensure the rationality of decisions (Weber \& Schäffer, 2019; Weber, 2019; Schäffer \& Weber, 2019; Zéman \& Lentner, 2018). In this approach, controlling is presented de facto as a method next to management, although it has a significant impact on the management (Horvath, 2002; Reichmann, 2012; Schäffer \& Brückner, 2019). Moreover, it is important to understand the difference between controlling and management accounting, especially form a modern point of view (Dijkman, 2019). This article adopted the concept of controlling derived from Germany and grounded in Polish theory and practice. In Polish organisations, controlling is most often seen as a managementsupport method (Goliszewski, 2015; Bieńkowska, Kral \& Zabłocka-Kluczka, 1998) referring to coordination (Horvath, 2002), which, thanks to its economic overtones, enables making right decisions in an organisation (Marciniak, 2008; Bieńkowska, 2015; Weber \& Schäffer, 2019; Weber, 2019) An important fact was emphasised by Goliszewski (1991), who stated that controlling did not replace management, but rather made management possible by supporting, giving opinions and advising.

However, it is not enough for an organisation to simply implement controlling to ensure its effectiveness. It is also vital to ensure the quality of controlling (Weber, 2001, 2011; Vollmuth, 2000; Nowosielski, 2014, 2018; Chalastra, 2010; Karwacki, 2011). The quality of controlling can be defined as "the degree to which the set of inherent properties of products (services, services) of controlling meets the requirements primarily of recipients of these products (managers and/or other recipients in the organisation), but also controllers - as the implementers of the idea of controlling" (Bieńkowska, 2015 , p. 221). Therefore, the quality of controlling refers to products (services) of controlling, i.e., the information generated by the controlling information 
system, including reports and controlling analyses, plans or budgets, as well as controlling services such as decision support, participation in planning, supervision of the control system or coordination of the planning processes in the organisation among other things (Bieńkowska, 2015). Therefore, the manifestations of the quality of controlling understood in this way and also seen as assessment measures that operationalise this construct, are in line with the expectations concerning the properties of controlling products, e.g.:

- timeliness, reliability, unambiguity and substantive adjustment to the formulated information requirements provided by controlling (Kowalak, 2009) postulates that the quality of the controlling system depends on the relevant information resources);

- a budgeting system that fulfils both incentive and informational functions;

- a planning and control system oriented towards a common goal for the organisation as a whole (Bieńkowska, 2015, p. 221).

\section{IMPACT OF CONTROLLING ON THE ORGANISATIONAL PERFOR- MANCE}

The explanation of the influence made by controlling on organisational performance and the development of the Controlling Effectiveness Model seems important from the point of view of theory and practice. The scale and strength of these controlling benefits determine the legitimacy of the implementation of controlling in an organisation as well as its effectiveness.

In the literature, the effectiveness of controlling is understood as "the relation (ratio) of the benefits of controlling functioning in an organisation to the costs of this functioning" (Bieńkowska, 2010, p. 299). It means that the more benefits and the fewer costs are directly related to the functioning of controlling, the greater is its effectiveness. In this approach, it is not enough to measure the parameters of the organisational functioning (e.g., in the form of the organisational performance level) to identify the effectiveness of controlling. It is also necessary (perhaps, at the very least) to identify the strength of the impact made by controlling on these parameters. Hence, the strength of the influence of controlling on organisational performance was adopted as the effectiveness of controlling in this study. At the same time, the quality of controlling should be considered rather than its implementation. Moreover, organisational performance as a result parameter concerns the costs of the organisational functioning in each of the analysed areas.

Besides, the influence made by controlling on an organisation as a whole does not seem to be direct. Therefore, in the construction of the Controlling Effectiveness Model, the direct relationship was mediated by the job performance of managers and employees. Hence, controlling influences organisational performance indirectly. This way, the Controlling Effectiveness Model characterises the impact, the place of each described variable and the direction of each relationship in the effort to shape organisational performance. The development stages of the Controlling Effectiveness Model are described below.

Looking at controlling through the prism of its quality primarily connects this management method with groups of stakeholders who use its products (services). Such an approach requires to consider the needs and expectations of various stakeholder groups of controlling. At the same time, it seems that the managers of individual responsibility centres and the top management of the organisation are the most important recipients of controlling services in the organisation. Other groups of important recipients are accounting and financial services, as well as line employees (Bieńkowska, 2015).

In light of the above, it is necessary to consider the impact made by the implementation of controlling on the work performed by managers. Certainly, as per Weber, it should be emphasised that the overarching goal for the implementation of controlling is "to increase the efficiency and effectiveness of management and to strengthen adaptation to changes occurring inside and outside the organisation" (Weber, 1991, p. 50; Sierpińska \& Niedbała, 2003, p. 15). Ensuring the management rationality is also indicated as the goal of controlling (Kuc, 2011; Zur Muehlen, 2002; Nowosielski, 2018; Weber, Schäffer, 2019; Weber, 2019; Schäffer \& Weber, 2019; Adegboye et al., 2019), which can be directly linked to "enabling managers to make more accurate (credible) decisions in the organisation" (Marciniak, 2008, p. 17), "management decision making" (Zoni \& Merchant, 2007), coordination of the management system (Küpper, 2008) or "improving the business management process" (Nowak 2003, p. 9) or improving management (Zur Muehlen, 2002, p. 72). 
Sierpińska and Niedbała (2003, p. 7) stated that controlling "provides various levels of management with cross-sectional information necessary to manage a future-oriented enterprise". Marciniak (2008) underlined that the main aim of controlling was to enable managers to make more accurate (credible) decisions in the organisation, which translated into an increase in management's involvement and direct participation in the decision-making process. Weber and Schäffer $(2019,2008)$, as well as Weber (2019), also stated that controlling was about the rationality assurance for management decisions. Hence, it turns out that the managerial staff of the organisation is a direct recipient of products offered by controlling, i.e. the "information generated by the controlling information system, including all kinds of reports and controlling analyses, plans or budgets" (Bieńkowska, 2015, p. 220-221). SkowronekMielczarek and Leszczyński (2007, p. 68) indicated that the "information security of value-oriented and result-oriented company management" was the main premise for the implementation of controlling. This opinion was also confirmed by Goto et al. (2014), claiming that the role of controllership was to "supply information for decision-making in an effective and efficient way, by supporting the process management, aiming to achieve the expected results". According to Sierpińska and Niedbała (2003, p. 7), controlling "provides various levels of management with the cross-sectional information necessary to manage a forward-looking enterprise". The statement was also confirmed by Laval (2015, p. 61), according to whom the "controlling function is shifting from data preparation to an active part in advising management".

At the same time, referring to the quality of controlling, and, thus, aiming to adapt its products (services) to the needs of managers in the organisation, Weber (2001, p. 67) emphasised that the low quality of controlling services translated into the low quality of decision-making cells. According to Vollmuth (2000, p. 205) "especially in larger enterprises, controlling is critically approached and is not particularly respected. There are often difficulties in communicating with management because reports are not always prepared in a way that is comprehensible to recipients". Weber and Nevries (2010) emphasised that the internal orientation of controlling on the customer affected the achieved quality of controlling services. This, in turn, implies an increase in the satisfaction of managers and their trust in controllers, resulting in a positive impact on their decisions and the activities of the organisation as a whole. According to the authors, it is very important to achieve broadly understood success, both in terms of "feelings" of managers expressed in the quality of their decisions, as well as in the scope of the organisation's activity as a whole (Weber \& Nevries, 2010, p. 17). Moreover, Bieńkowska et al. (2019a, 2019b) presented empirical evidence that the quality of controlling outputs actually shortened the decision-making time and resulted in the overall increase in the effectiveness of the organisation's management. According to Sova (2019), controlling is an effective enterprise management tool. The statements given above allow the following hypothesis:

H1. The quality of controlling directly influences the job performance of managers.

The implementation of controlling in an organisation seems to directly improve the job performance of employees in the organisation. Bieńkowska et all. (2019c) empirically verified the impact made by the implementation of controlling (measured by the time of its functioning in the organisation) on the job performance of employees, confirming the positive relationship between the studied variables. At the same time, job performance meant the effectiveness of employee activities, which contribute to the implementation of organisational goals (Forooqui \& Negendra, 2014, p. 95). When directly referring to the job performance of employees in relation to the quality of controlling, it is important to firstly consider the impact of specific products (services) of controlling on the work performed by employees. The empirical research by Bieńkowska et al. (2019a, 2019c) confirmed that the rising quality of controlling outputs caused, among others, an increase in satisfaction, employee morale and involvement in the achievement of results among other things. Chachuła (2009, p. 37) noted that the purpose of the implementation of controlling was, among other things, the orientation of cells on results. Therefore, first, employee access to controlling information should be considered. Nowogródzka and Szarek (2012, p. 86) noted that a well-organised controlling system allowed obtaining accurate, current and proper information and its better flow in the organisation, so employees who had access to the "right information" transmitted by controlling could use it in their work, thus increasing their own job performance. Moreover, according to Nowogródzka and Szarek (2012, p. 86), "the proper functioning of controlling enables coordination of all activities in individual areas of the organisation". Besides, 
employees participating in properly designed (in terms of controlling) budgeting processes can better understand the financial framework of requirements and limitations of their work. Küpper (2008; Guenther, 2013) also mentioned that coordination tools used in controlling within HRM, i.e. management principles, targeted setting incentive values, shared expectations and positive emotional interactions. According to Nowak (2003, p. 9) controlling "has become a response to the organisation's needs regarding the need to adapt to functioning in a highly variable environment and, in this context, it guarantees the improvement of the processes taking place in it." Moreover, Deneke (2018) indicated the improvement of the process effectiveness as an advantage arising from the implementation of controlling. Finally, it should be emphasised that the functioning of employees in responsibility centres properly designated as part of controlling, where employees felt co-responsible for achieving the set goals and the effectiveness of managing the entrusted resources (Nowosielski, 2001), helped to increase their job performance, which naturally contributed to the objectives of these reference systems. The considerations provide the basis for the following hypothesis:

$\mathrm{H} 2$. The quality of controlling directly influences the job performance of employees.

It should also be emphasised that employees are indirect beneficiaries of the controlling implemented in an organisation. In the organisation that implements controlling, managers apply the so-called controlling management (Bieńkowska, Kral \& Zabłocka-Kluczka, 1998), which is:

- planning based on controlling the budget, as well as the information and reporting controlling system, or the technique of management by objectives;

- $\quad$ organising teamwork based on separate centres of responsibility;

- controlling the work of the team and employees according to assessment measures proposed and analysed by controlling;

- motivating employees by creating remuneration systems and other measures based on solutions and information provided by controlling.

They all affect work performed by employees in an organisation. Thus, each time solutions based on the achievements of controlling are applied by managers, the indirect impact of the quality of controlling on the job performance of employees is emphasised.
Furthermore, the indirect impact of the quality of controlling on the job performance of employees means that controlling affects job performance indirectly, through the job performance of managers. Thus, the higher is the quality of controlling, the more efficient is the management and the more accurate are the decisions made by managers. Therefore, they perform their tasks better (as explained earlier) and have a more positive impact on their employees and the job performance of their employees. In view of the above, the following hypothesis is proposed:

H3. The quality of controlling influences the job performance of employees indirectly, through the job performance of managers.

The direct influence of managers on employees is a well-known mechanism because it is directly inscribed in the essence of management and is understood as the influence of superiors on subordinates (Witczak, 2008, p. 208). Therefore, the additional hypothesis is also valid:

H4. The job performance of manager directly influences the job performance of employees.

Moreover, it should be emphasised that both the job performance of employees and managers affect organisational performance. These relationships have been repeatedly examined and described in the literature (Forooqui \& Nagendra, 2014; Brewer \& Selden, 2000; Lado \& Wilson, 1994; Dessler, 2011; June \& Mahmood, 2011). Furthermore, the job performance of managers influences the organisational performance not only directly, but also indirectly, through the job performance of employees, which is obviously related to the earlier described nature of management (as the impact of superiors on subordinates aiming to achieve the assumed goals in the organisation as a whole) (Witczak, 2008). Therefore, the following additional hypotheses can be formulated:

H5. The job performance of managers influences organisational performance indirectly through the job performance of employees.

H6. The job performance of employees directly influences organisational performance.

H7. The job performance of managers directly influences organisational performance.

When considering the impact made by controlling on the functioning of the organisation as a whole, it is important to emphasise the unique diversity of benefits received from implemented controlling mentioned in the literature. Amann and Petzold (2014) underlined the crucial role of controlling in ensuring organisational success. These 
include, among other things, ensuring the continuity of the operation, stimulating the development and ensuring the development and improvement of the competitive position of the organisation (Bea, Friedl \& Schweitzer, 2005; Chachuła, 2009; Kuc, 2002); optimisation (maximisation) of the financial result and value of the organisation (Brzezin, 2001); and finally, improving the performance of the organisation as a whole (Nowosielski, 2001; Marciniak, 2008; Kuc, 2002). Hahn and Hungenberg (2001), Bieńkowska et al. $(2019$ a , 2019c) also found a direct connection between controlling and organisational performance as a synthetic measure that refers to the comprehensive results of the functioning of the entire organisation (Benčová \& Kalavská, 2009). According to Roman et al. (2014, p. 18), "balanced controlling represents the highest level in controlling development process".

While referring to the impact of the quality of controlling on the functioning of the organisation as a whole, it should be underlined that many authors emphasised the impact of the implementation of controlling on various parameters of the organisational functioning. However, the literature rarely offers views regarding the impact made by the quality of controlling on organisational performance. Nevertheless, "the usefulness of controlling in the process of management rationalisation is being questioned, there is the need to reduce controlling positions, arguing with the high costs of maintaining these services, the lack of translation into the financial result, poor work efficiency or low quality of services" (Nowosielski, 2011, p. 244). However, Bieńkowska et al. (2019b) and Tworek (2019) pointed to the positive relationships between the quality of controlling outputs and organisational performance.

Moreover, the impact made by controlling on organisational performance is indirect, as well as each of the above-mentioned objectives of controlling. The specified goals should rather connect to the goals of organisational management (also strategic management), and the controllers can influence their achievement only to some extent. "Controlling can have (and has) an impact on both ensuring the organisation's long-term existence and continuity of its functioning, but it is an indirect impact" (Bieńkowska, 2015, p. 60). In this context, there is a need to indicate mediators that explain the mechanism behind the indirect influence of controlling on the result constructs. This study adopts mediators in the form of variables considered in the literature to be direct objectives of controlling and resulting directly from its definition as a method of supporting management, namely, the job performance of managers and employees. This seems justified even more so by the results obtained by Bieńkowska et al. (2019c), who clearly confirmed that job performance is a mediator of the relationship between the use of controlling and organisational performance.

In the context of the relationship described above, it seems that there is a need to analyse the impact made by the quality of controlling on organisational performance while analysing the mediating role of the job performance of employees and managers. It will allow verifying the Controlling Effectiveness Model, which comprehensively explains the mediated influence made by the quality of controlling on organisational performance through the job performance of employees and managers. Therefore, in light of the above, the main hypothesis should be formulated as follows:

H8. The quality of controlling influences organisational performance indirectly through the job performance of managers and employees.

Fig. 1 presents the diagram illustrating the structure of the Controlling Effectiveness Model and the adopted research hypotheses H1-H7.

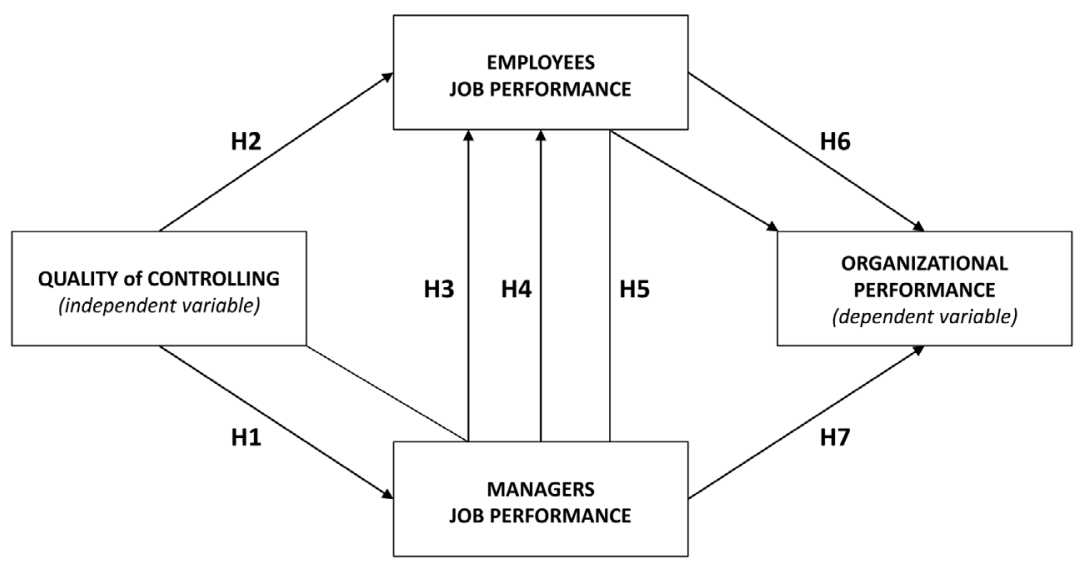

Fig. 1. Structure of the Controlling Effectiveness Model 


\section{RESEARCH METHODOLOGY}

\subsection{SAMPLE DESCRIPTION}

In October 2019, the survey was conducted on 246 organisations functioning in Poland to verify the proposed Controlling Effectiveness Model. The country of origin was the only condition limiting the sample, and the surveyed organisations were not randomly selected. The CAWI method was used. However, efforts had been made to ensure a diversified research sample in terms of varied organisations characteristics. The sample of characteristics is presented in Table 1. Although 231 organisations commented on the implementation of controlling, only those with implemented controlling were considered for research. Therefore, 188 organisations were included in the sample.

To verify a sufficient distribution of sample organisations in the population of all organisation, the used control variables were connected to main elements of an organisation and its environment: environment dynamics, environment unpredictability, environment complexity, production diversification, production repeatability, community-oriented culture, and employee education. The control variables were measured based on a single-item scale using a 5-point Likert scale (Table 2).

The normality of the distribution of control variables was verified using the Shapiro Wilk test and the Kolmogorow-Smirnow test (Table 2). Based on the tests, the sample was sufficiently diversified (contained organisations with all sets of characteristics) to draw general conclusions based on it.

\subsection{VARIABLE CHARACTERISTICS}

Variables quality of controlling (QCON), the job performance of managers (MPER), the job performance of employees (JPER) and organisational performance (ORGPER) were used to verify hypotheses. Appendix A provides items used to measure each of them.

Quality of controlling was measured based on four aspects: quality of reports and analysis of controlling, information delivered by controlling, budgets developed by controlling and controlling coordination (Bieńkowska, 2015). It was measured based on an 8-item scale (using a 5-point Likert scale).

Tab. 1. Research sample characteristics concerning organisation size and the implementation of controlling

\begin{tabular}{|c|c|c|c|}
\hline $\begin{array}{c}\text { ORGANISATION SIZE } \\
\text { CONTROLLING IMPLEMENTATION }\end{array}$ & $\begin{array}{l}\text { CONTROLLING } \\
\text { IS IMPLEMENTED }\end{array}$ & $\begin{array}{l}\text { CONTROLLING IS NOT } \\
\text { IMPLEMENTED }\end{array}$ & TOTAL \\
\hline Micro (below 10 people) & 21 & 14 & 35 \\
\hline Small (11-50 people) & 66 & 11 & 77 \\
\hline Medium (51-250 people) & 57 & 4 & 61 \\
\hline Large (above 250 people) & 42 & 14 & 56 \\
\hline Total & $186^{*}$ & 43 & 229 \\
\hline *2 organisations did not indicate their size & & & \\
\hline
\end{tabular}

Tab. 2. Normality of distribution of control variables

\begin{tabular}{|c|c|c|c|c|c|c|}
\hline \multirow{2}{*}{ CONTROL VARIABLES } & \multicolumn{3}{|c|}{ KOŁMOGOROW-SMIRNOW ${ }^{A}$} & \multicolumn{3}{|c|}{ SHAPIRO-WILK } \\
\hline & STATISTIC & DF & $P$ & StATISTIC & DF & $P$ \\
\hline The company's environment is constantly changing & 0.233 & 232 & 0.000 & 0.885 & 232 & 0.000 \\
\hline $\begin{array}{l}\text { Changes in the company's environment are } \\
\text { unpredictable }\end{array}$ & 0.203 & 232 & 0.000 & 0.901 & 232 & 0.000 \\
\hline The company's environment is complex & 0.264 & 232 & 0.000 & 0.868 & 232 & 0.000 \\
\hline The company offers a lot of different products & 0.250 & 232 & 0.000 & 0.887 & 232 & 0.000 \\
\hline $\begin{array}{l}\text { The manufacturing process is routine; tasks are } \\
\text { repetitive }\end{array}$ & 0.214 & 232 & 0.000 & 0.906 & 232 & 0.000 \\
\hline $\begin{array}{l}\text { Organisational culture is strong, and employees are } \\
\text { sharing it willingly }\end{array}$ & 0.247 & 232 & 0.000 & 0.890 & 232 & 0.000 \\
\hline Most employees have a higher degree of education & 0.191 & 232 & 0.000 & 0.911 & 232 & 0.000 \\
\hline
\end{tabular}


Job performance of employees was measured considering four aspects: job quality, job efficiency, punctuality and effectiveness of achieving goals at the workplace (Forooqui \& Negendra, 2014). It was measured based on a 4-item scale (using a 5-point Likert scale) (Bieńkowska et al., 2020).

Job performance of managers was measured considering four aspects: decision-making effectiveness, work efficiency, speed and precision of information transfer, and the effectiveness of achieving goals at the workplace (Bieńkowska et al., 2020). It was measured based on a 4 -item scale (using a 5-point Likert scale).

Organisational performance was measured using the concept of the Balanced Scorecard (Kaplan \& Norton, 1996; Handoko \& Wehartaty, 2017), which allowed including multiple aspects of organisational performance in four perspectives. Those perspectives were measured based on a 10-item scale (using a 5-point Likert scale) (Bieńkowska et al., 2020).

\subsection{DESCRIPTIVE STATISTICS AND THE RELI- ABILITY ANALYSIS OF SCALES}

The reliability of the scales of each variable was verified for the obtained research sample and is presented in Table 2. The Cronbach's $\alpha$, as well as the Factor Analysis, were calculated for the quality of controlling, the job performance of managers, the job performance of employees, and organisational performance. The results indicated high internal reliability of the scales and measurements. The Cronbach's a confirmed that scales were reliable (value above 0.8 ). The test confirmed the absence of collinearity issues. Therefore, the model could be built based on the given set of data (Table 3, last column).

\subsection{RESEARCH RESULTS}

First, r-Pearson's correlation analysis was performed (Table 4). The strength of the relationship was measured with r-Pearson's correlation coefficient. The relationship was considered strong when $r>0.7$, mild when $r>0.3$ and weak when $r<0.3$.
The obtained results (Table 4) show a statistically significant and high correlation between all analysed variables. However, it is definitely the highest in the case of the relationship between the job performance of managers as well as the job performance of employees and the organisational performance. Next, the multiple linear regression was used to determine whether the variables from the model indeed significantly influenced organisational performance, controlling the sample once again for variables connected to main elements of an organisation and its environment, i.e. dynamics, unpredictability and complexity of the environment; diversification and repeatability of production; and community-oriented culture and employee education. Two regression models were built: the first with control variables only, when R2 $=0.504$, meaning that $50.4 \%$ of the variation of the dependent variable was explained by the variation of independent variables; and the second with control variables and variables, which were to be used for the model development, when R2 $=0.715$, meaning that $71.5 \%$ of the variation of the dependent variable was explained by the variation of independent variables. Delta $\mathrm{R} 2=0.211(\mathrm{p}=0.001)$ was verified to be statistically significant. Therefore, the results justified performing model verification.

The path analysis was executed using SPSS AMOS to verify the Controlling Effectiveness Model. Based on the results, the place of each variable and the direction of each relationship were established. The model was verified as defined and well-fitted $($ Chi2 $(1)=25.796, \mathrm{p}<0.001$; CFI $=0.946$; RMSEA $=$ 0.364). The Chi-Square test showed that the model was statistically significant. Its fit was measured with CFI (which should be above 0.8) and RMSEA (which should be below 0.2). An overview of the model is presented in Table 5. Tables 6-8 contain the values of total, direct and indirect effects occurring among variables within the Controlling Effectiveness Model.

The obtained results show the internal structure of the Controlling Effectiveness Model. It was empirically verified that the quality of controlling influenced the organisational performance only indirectly through the management performance and

Tab. 3. Defined variables together with the results of the reliability analysis of scales and the test of collinearity

\begin{tabular}{|l|r|r|r|r|r|r|}
\hline \multicolumn{1}{|c|}{ VARIABLE } & No. OF SCALES & CRONBACH'S A & $\begin{array}{c}\text { FACTOR ANALYSIS } \\
\text { (\%) }\end{array}$ & M & SD & VFI \\
\hline QCON & 8 & 0.883 & 54.958 & 3.4051 & 0.77834 & 1.936 \\
\hline MPER & 4 & 0.839 & 67.473 & 3.5664 & 0.84513 & 2.283 \\
\hline JPER & 4 & 0.848 & 68.657 & 3.6283 & 0.90450 & 2.354 \\
\hline ORGPER & 10 & 0.883 & 48.762 & 3.4239 & 0.69953 & - \\
\hline
\end{tabular}


Tab. 4. Correlation analysis between analysed variables

\begin{tabular}{|c|c|c|c|c|}
\hline & & QCON & JPER & MPER \\
\hline \multirow[t]{3}{*}{ JPER } & $r$ & $0.645^{* *}$ & 1 & \\
\hline & $p$ & 0.000 & & \\
\hline & $\mathbf{N}$ & 187 & 187 & \\
\hline \multirow[t]{3}{*}{ MPER } & $r$ & $0.543^{* *}$ & $0.732^{* *}$ & 1 \\
\hline & $p$ & 0.000 & 0.000 & \\
\hline & $\mathbf{N}$ & 187 & 187 & 187 \\
\hline \multirow[t]{3}{*}{ ORGPER } & $r$ & $0.693^{* *}$ & $0.778^{* *}$ & $0.745^{* *}$ \\
\hline & $p$ & 0.000 & 0.000 & 0.000 \\
\hline & $\mathbf{N}$ & 175 & 175 & 175 \\
\hline
\end{tabular}

Tab. 5. Regression Weights

\begin{tabular}{|l|c|c|c|c|}
\hline & ESTIMATE & S.E. & C.R. & $\boldsymbol{P}$ \\
\hline MPER <--- QCON & 0.589 & 0.067 & 8.811 & $* * *$ \\
\hline JPER <--- MPER & 0.579 & 0.057 & 10.085 & $* * *$ \\
\hline JPER <--- QCON & 0.408 & 0.062 & 6.547 & $* * *$ \\
\hline ORGPER <--- JPER & 0.385 & 0.049 & 7.857 & $* * *$ \\
\hline ORGPER <--- MPER & 0.307 & 0.052 & 5.856 & $* * *$ \\
\hline
\end{tabular}

Tab. 6. Standardised Total Effects

\begin{tabular}{|l|r|r|r|}
\hline & \multicolumn{1}{|c|}{ QCON } & MPER & \multicolumn{1}{c|}{ JPER } \\
\hline MPER & 0.589 & 0.000 & 0.000 \\
\hline JPER & 0.749 & 0.579 & 0.000 \\
\hline ORGPER & 0.469 & 0.529 & 0.385 \\
\hline
\end{tabular}

Tab. 7. Standardised Direct Effects

\begin{tabular}{|l|r|r|r|}
\hline & \multicolumn{1}{|c|}{ QCON } & MPER & \multicolumn{1}{c|}{ JPER } \\
\hline MPER & 0.589 & 0.000 & 0.000 \\
\hline JPER & 0.408 & 0.579 & 0.000 \\
\hline ORGPER & 0.000 & 0.307 & 0.385 \\
\hline
\end{tabular}

Tab. 8. Standardised Indirect Effects

\begin{tabular}{|l|r|r|l|}
\hline & \multicolumn{1}{|c|}{ QCON } & MPER & \multicolumn{1}{c|}{ JPER } \\
\hline MPER & 0.000 & 0.000 & 0.000 \\
\hline JPER & 0.341 & 0.000 & 0.000 \\
\hline ORGPER & 0.469 & 0.223 & 0.000 \\
\hline
\end{tabular}

the job performance of employees. At the same time, it was important that, apart from the direct impact of the quality of controlling on the job performance of employees, the indirect impact through performance management was also significant. The strongest effect between controlling the quality and organisational performance occurred in the case of sequentially mediated relationship through the management performance (the indirect effect $=0.341$ ) and the job performance (the indirect effect $=0.223$ ). However, the effects occurring through single mediation (the quality of controlling - job performance organisational performance and the quality of controlling - management performance organisational performance) were high enough to be included in the model as well. The obtained results allowed accepting hypotheses 1-8.

\section{DISCUSSION}

The article aimed to explain how controlling affected the results of organisational functioning. In particular, the analysis focused on the impact made by controlling on the job performance of employees and managers and on the organisational performance, aiming to build the mediation model (the Controlling Effectiveness Model) and confirming that controlling affected the organisational performance through the influence on the job performance of managers and employees. The obtained results confirmed the adopted assumptions. They allowed confirming that the job performance of employees and managers was the mediator of the relationship between the quality of controlling and the organisational performance. This finding proved the indirect impact of the quality of controlling on the functioning of the organisation as a whole, which confirmed the initial findings (Bieńkowska, 2015). The first part of the model confirmed that the quality of controlling affected the job performance of managers directly, which was consistent with the observations by Weber (1991), Kuc (2011), Nowosielski (2018) or Zur Muehlen (2002) and results provided by, e.g., Bieńkowska (2015) or Bieńkowska et al. (2019b), showing that controlling as a management-support method increased quality and also positively influenced decisions made by managers. It was also confirmed by Marciniak (2008). Another finding, which is also important and not entirely obvious, was that controlling also affected the employees of the organisation. The effects were found to be direct and indirect, with the latter being slightly weaker. Therefore, employees were a direct user of the products and services offered by controlling, i.e., the information and reporting system, as well as budgeting (Bieńkowska et al., 2019a, 2019b; Küpper, 2008). In addition, they were influenced by the so-called controlling management, i.e., actions of managers using controlling tools and the controlling way of thinking (Bieńkowska, Kral \& ZabłockaKluczka, 1998). 
Looking at the other side of the Controlling Effectiveness Model, i.e., the impact of the studied variables on the organisational performance, it can be stated that the direct impact of both the job performance of managers and employees on the organisational performance was verified, which confirmed the statements contained in the literature (Forooqui \& Negendra, 2014; Brewer \& Selden, 2000).

Furthermore, the indirect impact of the job performance of managers on the organisational performance through the job performance of employees was also proved. In the above context, the Controlling Effectiveness Model should be considered validated. It should be noted that the quality of controlling has the strongest impact on the job performance of managers, and managers then influence the work performed by subordinates, which in turn translates into organisational performance. The verified Controlling Effectiveness Model is shown in Fig. 2.

\section{CONCLUSIONS}

The empirical research performed to verify the Controlling Effectiveness Model based on the literature review allowed confirming that:

- there was a statistically significant indirect impact of the quality of controlling on organisational performance;

- the job performance of managers and employees was a mediator of that relationship.

Hence, it seemed to be a valid conclusion that the quality of controlling was one of the factors influencing organisational performance. The developed model contributes to epistemological knowledge and also has practical significance. The quality of controlling in the process of shaping organisational performance is significant. In this context, organisations that decide to implement controlling should emphasise special care for the quality of this management support method. In this context, it is also relevant to properly shape functional, organisational and instrumental solutions of controlling (tailored to the characteristics of an organisation as a whole, as well as to the environmental conditions, under which these organisations operate), which determine the quality of controlling.

The performed research has some limitations. The sample was limited to organisations operating in Poland only. Therefore, conclusions could be drawn regarding the concept of controlling derived from German perception of controlling as a managementsupport method. However, in the future, there is a need to expand research to countries where US-based controlling is implemented. Moreover, the research should serve as a starting point for further analysis of controlling in an organisation. For example, as indicated in the literature, in the context of conditions (prerequisites) for effective implementation and efficient functioning of controlling in an organisation, it is important to indicate the moderating impact of individual conditions, which will be enabled by the Controlling Effectiveness Model. It can be assumed that some of the conditions will critically affect the relationship between the quality of controlling and organisational performance, such as the reliability of IT solutions in the organisation. Some others will have a smaller impact, such as the use of specific management techniques for controlling. Hence, the obtained results not only allowed filling in the indicated research gap but also created future directions of research.

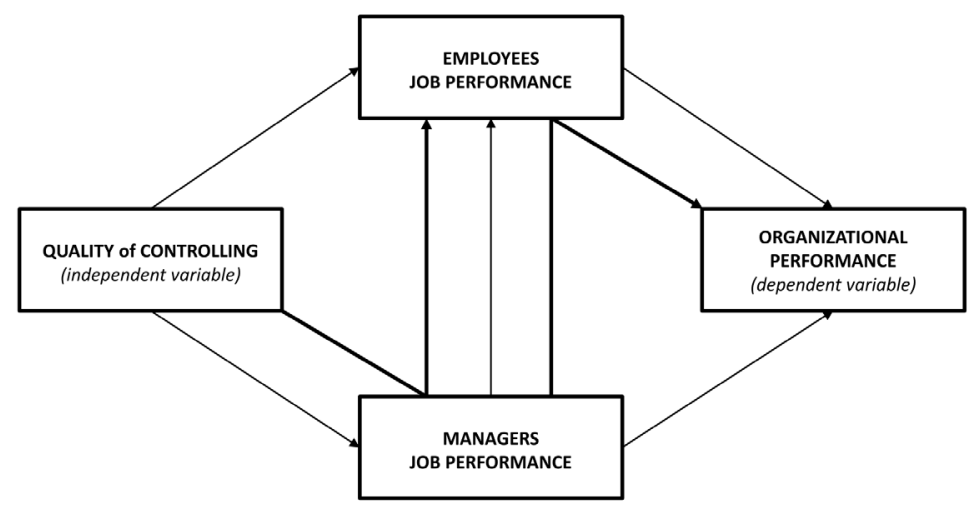

Fig. 2. Verified Controlling Effectiveness Model 


\section{LITERATURE}

Adegboye, A., Ojeka, S., Adegboye, K., Ebuzor, E., \& Samson, D. (2019). Firm performance and condensed corporate governance mechanism: evidence of Nigerian financial institutions. Business: Theory and Practice, 20, 403-416. doi: 10.3846/btp.2019.38

Amann, K., \& Petzold, J. (2014). Management und Controlling: Instrumente-Organisation-Ziele. Springer-Verlag. doi: 10.1007/978-3-658-28795-5

Anthony, R. N., \& Govindarajan, V. (2007). Management control systems. 12th ed. Boston: McGraw-Hill/Irwin.

Bea, F., Friedl, B., \& Schweitzer, M. (2005). Allgemeine Betriebwirtschftslehre. Stuttgart, Germany: Lucius UTB.

Benčová, M., \& Kalavská, A. (2009). Importance of the Controllership for the Company Performance-Software Company Experience. Ekonomie a Management, 2, 76-83.

Bieńkowska, A. (2010). Controlling - w pogoni za efektywnością? [Controlling - in the drive for efficiency ?]. In E. Skrzypek (Ed.), Etyka a jakość i efektywność organizacji [Ethics and the quality and effectiveness of the organization]. Lublin, Poland: Wyd. UMCS.

Bieńkowska, A. (2015). Analiza rozwiazań i wzorce controllingu $w$ organizacji [Analysis of solutions and controlling patterns in the organization]. Wrocław, Poland: Oficyna Wydawnicza Politechniki Wrocławskiej.

Bieńkowska, A., \& Zgrzywa-Ziemak, A. (2011). Współczesne metody zarządzania w przedsiębiorstwach funkcjonujacych w Polsce - identyfikacja stanu istniejącego [Contemporary management methods in enterprises operating in Poland - identification of the current state]. In M. Hopej, Z. Kral (Eds.), Współczesne metody zarządzania $w$ teorii i praktyce [Contemporary management methods in theory and practice] (pp. 211-252). Wrocław, Poland: Oficyna Wydawnicza Politechniki Wrocławskiej.

Bieńkowska, A., Kral, Z., \& Zabłocka-Kluczka, A. (1998). Zarządzanie kontrolingowe czy tradycyjne? [Controlling or traditional management?]. Prace Naukowe Instytutu Organizacji i Zarzadzania Politechniki Wrocławskiej, 21(68), 288-295.

Bieńkowska, A., Sałamacha, A., \& Tworek, K. (2020). The role of employees in shaping brand performance. Forum Scientiae Oeconomia, 8(2), 93-107. doi: 10.23762/FSO_VOL8_NO2_6

Bieńkowska, A., Tworek, K., \& Zabłocka-Kluczka, A. (2019a). IT Reliability and the Results of Controlling. In Z. Wilimowska, L. Borzemski, \& J. Świątek (Eds.), ISAT 2018. Information Systems Architecture and Technology: Proceedings of 39th International Conference on Information Systems Architecture and Technology - ISAT 2018. Advances in Intelligent Systems and Computing, 854 (pp. 222234). Cham: Springer. doi: 10.1007/978-3-31999993-7_20

Bieńkowska, A., Tworek, K., \& Zabłocka-Kluczka, A. (2019b). IT reliability and its influence on the results of controlling: comparative analysis of organizations functioning in Poland and Switzerland. Information Systems Management, 37(1), 33-51. doi: 10.1080/10580530.2020.1696545

Bieńkowska, A., Tworek, K., \& Zabłocka-Kluczka, A. (2019c). Moderating role of UX and IT reliability in controlling influence on job performance and orga- nizational performance. Ekonomie \& Management, in press.

Bieńkowska, A., Tworek, K., \& Zabłocka-Kluczka, A. (2020). Organizational Reliability: Human Resources, Information Technology and Management. New York, USA: Routledge. doi: 10.4324/9781003047995

Brewer, G. A., \& Selden, S. C. (2000). Why elephants gallop: Assessing and predicting organizational performance in federal agencies. Journal of Public Administration Research and Theory, 10(4), 685-711. doi: 10.1093/oxfordjournals.jpart.a024287

Brzezin, W. (2001). Controlling. Modele teoretyczne-normatywne do zastosowania w przedsiębiorstwach polskich [Controlling. Theoretical-normative models to be used in Polish enterprises]. Częstochowa, Poland: Częstochowskie Wydawnictwo Naukowe.

Chachuła, D. (2009). Controlling. Koncepcje, narzędzia, modele [Controlling. Concepts, tools, models].Warszawa, Poland: Difin.

Chalastra, M. (2010). Audyt systemu controlling [Audit of the controlling system]. Controlling i Rachunkowość Zarzadcza, 10, 21-28.

Chenhall, R. H. (2003). Management control systems design within its organizational context: findings from contingency-based research and directions for the future. Accounting, Organizations and Society, 28 (2-3), 127-168.

Dellmann, K. (1992). Eine Systematisierung der Grundlagen des Controlling. In K. Spremann, \& E. Zur (Eds.) Controlling. Grundlagen Informationssysteme - Anwendungen (pp. 113-140). Wiesbaden, Germany: Publishing House.

Deneke, A. (2018). Integrated information systems: The influence on process performance in management accounting. Junior Management Science, 3(1), 123-159.

Dessler, G. (2011). Human Resource management (12th ed.). Prentice-Hall.

Deyhle, A. (1976). Management and Controlling Brevier: Bd. 1: Manager and Controller in Team. Management Service Verlag.

Dijkman, A. (2019). The activities of management accountants: results from a survey study. Management Accounting Quarterly, 20(2), 29-37.

Forooqui, M. S., \& Nagendra, A. (2014). The impact of person organization fit on job satisfaction and performance of the employees. Procedia economics and Finance, 11, 122-129. doi: 10.1016/s22125671(14)00182-8

Goliszewski, J. (1991). Controlling, cz. V: System controlling [Controlling, part V: Controlling system]. Przeglad Organizacji, 4, 22-23. doi: 10.33141/po.1991.04.08

Goliszewski, J. (2015). Controlling. Koncepcja, zastosowania, wdrożenie [Controlling. Concept, applications, implementation]. Warszawa, Poland: Wolters Kluwer business.

Goto, E. V. H., Parisi, C., \& Slomski, V. G. (2014). The influence of contingency factors in the area of divisional controllership in foreign subsidiaries of a multinational organization. Business and Management Review, 4(3), 367-382.

Granlund, M., \& Taipaleenmäki, J. (2005). Management control and controllership in new economy firms a life cycle perspective. Management Accounting Research, 16(1), 21-57. doi: 10.1016/j.mar.2004.09.003

Guenther, T. W. (2013). Conceptualisations of 'controlling' in German-speaking countries: analysis and com- 
parison with Anglo-American management control frameworks. Journal of Management Control, 23(4), 269-290. doi: 10.1007/s00187-012-0166-7

Hahn D., \& Hungenberg H. (2001). Planung und Kontrolle - Planungs- und Kontrollsysteme - Planungs- und Kontrollerechtung. Wertorientierte Controllingkonzepte, 6. Aufl. Wiesbaden, Germany: Springer Gabler. doi: 10.1007/978-3-322-90764-6_2

Handoko, J., \& Wehartaty, T. (2017). Strategic Balanced Scorecard implementation in controlling bias and conflict. Polish Journal of Management Studies, 15(1), 57-65. doi: 10.17512/pjms.2017.15.1.06

Horvath, P. (2002, 2006). Controlling. München, Germany: Verlag Franz Vahlen.

Jackson, J. H. (1949). The growth of the controllership function. In T. F. Bradshaw, C. H. Hull, \& D. R. Anderson (Eds.), Controllership in modern management. Chicago, USA: R. D. Irwin.

Janka, M., \& Günther, T. (2020). Controlling für agiles Management. Controlling Management Review, 64, 24-33. doi: 10.1007/s12176-020-0117-3

June, S., \& Mahmood, R. (2011). The relationship between person-job fit and job performance: A study among the employees of the service sector SMEs in Malaysia. International Journal of Business, Humanities and Technology, 1(2), 95-105.

Kaplan, R. S., \& Norton, D. P. (1996). The balanced scorecard: translating strategy into action. Boston, USA: Harvard Business School Press.

Karwacki, P. (2011). Czynniki ograniczające efektywność controllingu $\mathrm{w}$ przedsiębiorstwie [Factors limiting the effectiveness of controlling in an enterprise]. In A. Barabasz, \& J. Skalik (Eds.), Współczesne przeobrażenia procesów zarządczych przedsiębiorstwa [Contemporary transformations of enterprise management processes] (pp. 110-119). Wrocław, Poland: Uniwersytet Ekonomiczny we Wrocławiu.

Kowalak, R. (2009). Benchamarking jako metoda wspomagająca controlling przedsiębiorstwa [Benchmarking as a method supporting company controlling]. Wrocław, Poland: Uniwersytet Ekonomiczny we Wrocławiu.

Kuc, B. R. (2002). Teoria i praktyka kontrolingu [Theory and practice of controlling]. In B. R. Kuc (Ed.), Kontrola $i$ kontroling $w$ zarzadzaniu: tendencje, koncepcje, instrumenty, cz. 2 [Control and controlling in management: trends, concepts, instruments, part 2]. Warszawa, Poland: Wyd. WSZiM.

Kuc, B. R. (2011). Kontroling dla menedżerów [Controlling for managers]. Warszawa, Poland: Helion.

Küpper, H.-U. (2008). Controlling - Konzeption, Aufgaben, Instrumente (5th ed.). Stuttgart, Germany: SchäfferPoeschel.

Lado, A. A., \& Wilson, C. M. (1994). Human resource systems and sustained competitive advantage: A competency-based perspective. Academy of Management Review, 19, 699-727. doi: 10.5465/ amr.1994.9412190216

Laval, V. (2015). Impact of recent megatrends on the controlling role model. Procedia Economics and Finance, 27, 54-63. doi: 10.1016/s2212-5671(15)00971-5

Lisiński, M., Sroka, W., \& Brzeziński, P. (2012). Nowoczesne koncepcje zarządzania w kierowaniu przedsiębiorstwami - wyniki badań [Modern management concepts in enterprise management - research results]. Przeglad Organizacji, 1, 26-30. doi: 10.33141/ po.2012.01.07

Luther, R., Jones C., \& Saxl, A. (2010). Experiencing change in German controlling: management accounting in a globalising world. CIMA Executive Research Summaries Series, 5(12), 1-6. doi: 10.1016/j.bar.2010.10.002

Maletic, M., Maletic, D., Dahlgaard, J., Dahlgaard-Park, S. M., \& Gomišcek, B. (2015). Do corporate sustainability practices enhance organizational economic performance? International Journal of Quality and Service Sciences, 7(2/3), 184-200.

Malmi, T., \& Brown, D. A. (2008). Management control systems as a package - Opportunities, challenges and research directions. Management Accounting Research, 19(4), 287-300. doi: 10.1016/j.mar.2008.09.003

Marciniak, S. (2008). Controlling. Teoria, zastosowania [Controlling. Theory, applications]. Warszawa, Poland: Difin.

Mocanu, M. (2014). Towards a definition of controlling. Studies and Scientific Researches. Economics Edition, 20, 62-66. doi: 10.29358/sceco.v0i20.295

Nowak, E. (2003). Istota i zakres controllingu [The essence and scope of controlling]. In E. Nowak (Ed.), Controlling $w$ przedsiębiorstwie. Koncepcje $i$ instrumenty [Controlling in the enterprise. Concepts and instruments]. Gdańsk, Poland: ODDK.

Nowogródzka, T., \& Szarek, S. (2012). Wpływ wprowadzania controllingu w przedsiębiorstwie na rentowność produkcji [The impact of introducing controlling in the enterprise on the production profitability]. Wspótczesne Zarządzanie, 1, 85-94.

Nowosielski, K. (2011). Kierunki usprawniania procesów controllingu [Directions of improving controlling processes]. Prace Naukowe Uniwersytetu Ekonomicznego we Wrocławiu, 169, 243-254.

Nowosielski, K. (2014). Quality of controlling process outputs in theory and practice. The International Conference Hradec Economic Days 2014: Economic Development and Management of Regions (pp. 83-91). Hradec Králové, Czech Republic: Gaudeamus.

Nowosielski, K. (2018). Sprawność procesów controllingowych. Istota. Przejawy. Determinanty [Efficiency of controlling processes. Being. Manifestations. Determinants]. Wrocław, Poland: Wyd. UE we Wrocławiu.

Nowosielski, S. (2001). Centra kosztów i centra zysku $w$ przedsiębiorstwie [Cost centers and profit centers in the enterprise]. Wrocław, Poland: Wyd. Akademii Ekonomicznej im. O. Langego we Wrocławiu.

Otley, D. (1994). Management control in contemporary organizations: towards a wider framework. Management Accounting Research, 5(3-4), 289-299. doi: 10.1006/mare.1994.1018

Otley, D. (1999). Performance management: a framework for management control systems research. Management Accounting Research, 10(4), 363-382. doi: 10.1006/mare.1999.0115

Otley, D., Emmanuel, C., \& Merchant, K. (2013). Readings in accounting for management control. Springer. doi: 10.1007/978-1-4899-7138-8

Reichmann, T. (2011). Controlling mit Kennzahlen und Management-Tools. Die systemgestützte ControllingKonzeption (8th ed.). München, Germany: Vahlen.

Reichmann, T. (2012). Controlling: concepts of management control, controllership, and ratios. Springer Science \& Business Media. 
Richard, P. J., Devinney, T. M., Yip, G. S., \& Johnson, G. (2009). Measuring organizational performance: Towards methodological best practice. Journal of Management, 35(3), 718-804. doi: $10.1177 / 0149206308330560$

Roman, C., Roman, A. G., Meier, E., \& Mocanu, M. (2014). Research on the evolution of controlling tasks and their delimitation from audit tasks. Theoretical \& Applied Economics, 21(12), 13-26.

Rylková, Ž. (2015). Measurement of business performance in relation to competitors, Engineering Management in Production and Services, 7(2), 13-19. doi: 10.12846/j.em.2015.02.02

Schäffer, U., \& Binder, C. (2008). Controlling' as an academic discipline: The development of management accounting and management control research in German-speaking countries between 1970 and 2003. Accounting History, 13, 33-74. doi: $10.1177 / 1032373207083926$

Schäffer, U., \& Brückner, L. (2019). Rollenspezifische Kompetenzprofile für das Controlling der Zukunft. Controlling \& Management Review, 63(7), 14-31. doi: 10.1007/s12176-019-0046-1

Schäffer, U., \& Weber, J. (2019). Truly rational decisions. In Behavioral controlling (pp. 169-178). Wiesbaden, Germany: Springer Gabler. doi: 10.1007/978-3-65825983-9_11

Schäffer, U., Weber, J., \& Prenzler, C. (2001). Characterising and Developing Controller Tasks-A German Perspective. 5th International Management Control Systems Research Conference, 4-6.

Sierpińska, M., \& Niedbała, B. (2003). Controlling operacyjny $w$ przedsiębiorstwie [Operational controlling in the enterprise]. Warszawa, Poland: Wyd. Naukowe PWN.

Skowronek-Mielczarek, A., \& Leszczyński, Z. (2007). Controlling: analiza $i$ monitoring $w$ zarzadzaniu przedsiębiorstwem [Controlling: analysis and monitoring in enterprise management]. Warszawa, Poland: Difin.

Sova, O. (2019). Controlling as an Effective Enterprise Management Tool. Accounting and Finance, 4, 119123. doi: 10.33146/2307-9878-2019-4(86)-119-123

Strauß, E., \& Zecher, C. (2013). Management control systems: a review. Journal of Management Control, 23(4), 233-268. doi: 10.1007/s00187-012-0158-7

Sujová, A., Marcineková, K., \& Simanová, L. (2019). Influence of modern process performance indicators on corporate performance - the empirical study. Engineering Management in Production and Services, 11(2), 119-129. doi: 10.2478/emj-2019-0015

Tworek, K. (2019). Aligning IT with business. Cham, Switzerland: Springer. doi: 10.1007/978-3-030-11563-0

Tworek, K., \& Sałamacha, A. (2019). CRM influence on organisational performance - the moderating role of IT reliability. Engineering Management in Production and Services, 11(3), 96-105. doi: 10.2478/emj-20190024

Vollmuth, H. J. (2000). Controlling. Planowanie, kontrola, zarzadzanie [Controlling. Planning, control, management]. Warszawa, Poland: Placet.

Wagenhofer, A. (2006). Management accounting research in German-speaking countries. Journal of Management Accounting Research, 18(1), 1-19. doi: 10.2308/ jmar.2006.18.1.1
Weber, J. (1991). Einfuhrung in das Controlling. Stuttgart, Germany: Schäffer-Poeschel Verlag.

Weber, J. (2001). Wprowadzenie do controllingu [Introduction to controlling]. Katowice, Poland: Oficyna Wydawnicza Profit.

Weber, J. (2011). The development of controller tasks: explaining the nature of controllership and its changes. Journal of Management Control, 22, 25-46. doi: 10.1007/s00187-011-0123-x

Weber, J. (2019). Controlling-developmental trends and future perspectives. In Behavioral Controlling (pp. 125-144). Wiesbaden, Germany: Springer Gabler. doi: 10.1007/978-3-658-25983-9_8

Weber, J., \& Nevries, P. (2010). Drivers of successful controllership. Activities, people and connecting with management. New York: Business Expert Press, LLC. doi: 10.4128/9781606491058

Weber, J., \& Schäffer, U. (2000). Controlling als Koordinationsfunktion? KRP-Kostenrechnungspraxis, 2(44), 109-118. doi: 10.1007/bf03249542

Weber, J., \& Schäffer, U. (2019). Is ensuring management rationality a controlling task? In Behavioral Controlling (pp. 87-111). Wiesbaden, Germany: Springer Gabler. doi: 10.1007/978-3-658-25983-9_6

Witczak, H. (2008). Natura i ksztattowanie systemu zarzadzania przedsiebiorstwem [Nature and shaping of the enterprise management system]. Warszawa, Poland: PWN.

Zéman, Z., \& Lentner, C. (2018). The changing role of going concern assumption supporting management decisions after financial crisis. Polish Journal of Management Studies, 18(1), 428-441. doi: 10.17512/ pjms.2018.18.1.32

Zimniewicz, K. (2013). Problem weryfikacji koncepcji zarządzania [The problem of verification of the management concept]. In J. Lichtarski (Ed.), Przedsiębiorczość i zarządzanie. Współczesne koncepcje, metody $i$ narzędzia zarzadzania. Przykłady i problemy zastosowań [Entrepreneurship and management. Contemporary concepts, methods and tools of management. Examples and problems of applications] (pp. 167-169). Ostrów Wielkopolski, Poland: Społeczna Akademia Nauk.

Zoni, L., \& Merchant, K. A. (2007). Controller involvement in management: an empirical study in large Italian corporations. Journal of Accounting \& Organizational Change, 3(1), 29-43. doi: 10.1108/18325910710732849

Zur Muehlen, M. (2004). Workflow-Based Process Controlling: Foundation, Design, and Application of Workflow-driven. Process Information System. Berlin, Germany: Logos. 


\section{Appendix A}

Tab. A1. Factor analysis for the variable "quality of controlling"

\begin{tabular}{|l|r|r|}
\hline \multicolumn{1}{|c|}{ FACTOR ANALYSIS } & $\begin{array}{c}\text { BEFORE } \\
\text { SEPARATION }\end{array}$ & $\begin{array}{c}\text { AFTER } \\
\text { SEPARATION }\end{array}$ \\
\hline Reports and analyses provided by controlling do not contain any errors & 1.000 & 0.470 \\
\hline Reports and analyses of controlling are valid and delivered on time & 1.000 & 0.582 \\
\hline The information contained in reports and controlling analyses is reliable & 1.000 & 0.563 \\
\hline $\begin{array}{l}\text { The information contained in reports and controlling analyses is indispensable in decision-mak- } \\
\text { ing processes/improve decision-making }\end{array}$ & 1.000 & 0.518 \\
\hline Budgets developed by controlling allow rationalising the costs in the company & 1.000 & 0.567 \\
\hline Budgets developed by controlling are an effective control tool in the company & 1.000 & 0.522 \\
\hline Budgets developed by controlling bring order to particular areas of the company & 1.000 & 0.585 \\
\hline Controlling coordination has a positive effect on the objectives of the organisation as a whole & 1.000 & 0.590 \\
\hline
\end{tabular}

Tab. A2. Factor analysis for the variable "job performance of employees"

\begin{tabular}{|l|r|r|}
\hline \multicolumn{1}{|c|}{ FACTOR ANALYSIS } & \multicolumn{2}{c|}{ BEFORE } \\
\hline JOB PERFORMANCE OF EMPLOYEES & $\begin{array}{c}\text { AFTER } \\
\text { SEPARATION }\end{array}$ & 1.000 \\
\hline Job quality & 1.000 & 0.701 \\
\hline Job efficiency & 0.699 \\
\hline Punctuality & 1.000 & 0.679 \\
\hline Effectiveness of achieving goals at the workplace & 1.000 & 0.668 \\
\hline
\end{tabular}

Tab. A3. Factor analysis for the variable "job performance of managers"

\begin{tabular}{|c|c|c|}
\hline \multicolumn{3}{|l|}{ FACTOR ANALYSIS } \\
\hline JOB PERFORMANCE OF MANAGERS & $\begin{array}{l}\text { BEFORE } \\
\text { SEPARATION }\end{array}$ & $\begin{array}{l}\text { AFTER } \\
\text { SEPARATION }\end{array}$ \\
\hline $\begin{array}{l}\text { Decision-making effectiveness (accuracy of decisions in terms of substantive expectations, } \\
\text { timeliness of decisions, etc.) }\end{array}$ & 1.000 & 0.721 \\
\hline Work efficiency (saving the resources available to the company) & 1.000 & 0.695 \\
\hline Speed and precision of information transfer & 1.000 & 0.653 \\
\hline Effectiveness of achieving goals at the workplace & 1.000 & 0.629 \\
\hline
\end{tabular}

Tab. A4. Factor analysis for the variable "organisational performance"

\begin{tabular}{|l|r|r|}
\hline \multicolumn{1}{|c|}{ FACTOR ANALYSIS } & BEFORE \\
\hline ORGANISATIONAL PERFORMANCE & $\begin{array}{c}\text { AFTER } \\
\text { SEPARATION }\end{array}$ \\
\hline OveraRATION & 1.000 & 0.461 \\
\hline Job performance & 1.000 & 0.484 \\
\hline Quality of products or services (reliability, diligence) & 1.000 & 0.439 \\
\hline Innovativeness of products or services & 1.000 & 0.438 \\
\hline Modernity of applied technological solutions & 1.000 & 0.468 \\
\hline Efficiency of the organisation management & 1.000 & 0.541 \\
\hline Reliability of business processes & 1.000 & 0.471 \\
\hline Market share & 1.000 & 0.490 \\
\hline Customers satisfaction & 1.000 & 0.567 \\
\hline Employee satisfaction & 1.000 & 0.517 \\
\hline
\end{tabular}

